Article

\title{
Real Exchange Rate Misalignment and Economic Growth: The Case of Trinidad and Tobago
}

\author{
Daren Conrad and Jaymieon Jagessar *(1) \\ Department of Economics, The University of the West Indies, St. Augustine Campus, St. Augustine, \\ Trinidad and Tobago; daren.conrad@sta.uwi.edu \\ * Correspondence: jay_jagassar@yahoo.com; Tel.: +1-868-662-2002 (ext. 83053)
}

Received: 23 June 2018; Accepted: 17 September 2018; Published: 21 September 2018

\begin{abstract}
Empirical studies outline developing countries' experience economic growth through an undervalued exchange rate and that exchange rate overvaluations have negative long term effects on economic growth. This paper examined the impact of exchange rate movements as well as exchange rate misalignments on economic growth for the Trinidad and Tobago economy over the period 1960 to 2016. We find statistically significant evidence that both exchange rate appreciation and misalignments impact negatively on economic growth in the T\&T economy. Drilling deeper, we find interestingly that there exist no non-linear effects of exchange rate misalignments on growth. Specifically, we find statistically significant evidence that both overvaluations and under valuations hamper economic growth in the Trinidad and Tobago economy. We attribute this to T\&T's small and underdeveloped manufacturing sector that tends to be overlooked on account of its energy resources, in addition to the fact that its manufacturing sector is highly import oriented. A major policy recommendation would be for the critical reassessment of the rules governing the Heritage and Stabilization Fund (HSF), as government expenditure was allowed to follow energy revenues due to its current limitations.
\end{abstract}

Keywords: exchange rate misalignment; real effective exchange rate; undervaluation; overvaluation; growth; autoregressive distributed lag bounds testing approach; Trinidad and Tobago

JEL Classification: F31; O47; C23

\section{Introduction}

Exchange rates powerfully affect cross-border economic transactions, according to Frieden (2008). "Trade, investment, finance, tourism, migration, and more are inextricably linked to and influenced by international monetary policy", see Frieden (2008, p. 344). To this end, there is an abundance of theoretical and empirical evidence that overwhelmingly highlights the increasing importance of exchange rates in the face of globalization (see Frieden 2008). A competitive exchange rate is a condition for economic growth (Gala and Lucinda 2006) ${ }^{1}$. Yet, since the 1990s, this condition is not present in most developing countries (Bresser-Pereira 2008). Most developing countries do not have the "relatively devaluated" exchange rate which Bresser-Pereira referred to as a competitive exchange rate. The idea of the competitive real exchange rate has received a lot of attention in both academic and political circles, (see Sokolova 2015). In the Caribbean, Blackman (2002) noted that the exchange rate is the most important price since it determines the terms of trade as well as the relative prices within an economy.

1 A competitive exchange rate refers to the mid-market rate or a rate that is very near to the mid-market rate. 
Doroodian et al. (2002) posit that it is a general consensus among researchers that the state must pursue an appropriate exchange rate policy as part of its liberalization effort in order to strengthen the competitiveness of domestic firms against established foreign firms. In other words, maintaining the real exchange rate at the "wrong" level can have negative effects on the nation's competitiveness. The authors further highlight that the inadequacy of economic performance has been the result of inappropriate exchange rate policies. Johnson et al. (2006) argue that exchange rate policy is a "lever for growth" even in countries with relatively weak institutions.

The policy advice that governments usually receive on exchange rates have been typically presented as theoretical solutions to economic problems. However, we cannot ignore the fact that exchange rate policy is a politically charged issue since it impacts all citizens; some favorably and some not so favorably. As such, policy-makers are generally more concerned with the impact of currency policy on electoral conditions and potentially, pressures from special interest groups.

Within recent times, Trinidad and Tobago's (T\&T's) foreign reserves have been waning on account of the unexpected decline in oil prices experienced in mid-2014; with the state doing its best to manage the currency float. The price of oil took a severe turn in mid-2014, plummeting to all-time lows in over ten years; remaining depressed over the last couple of years, barring a slight recovery in recent times ${ }^{2}$. This decline in reserves resulted in foreign currency shortages in the banking sector in Trinidad and Tobago which has ignited a debate on whether T\&T's exchange rate is overvalued or not. The International Monetary Fund (IMF) Article IV 2016 for the Trinidad and Tobago economy found that that the Trinidad and Tobago currency is substantially overvalued in the range of 21.3 to $50 \%$.

Edwards (1989) argues that real exchange rate misalignments may affect growth and welfare. Maintaining the real effective exchange rate (REER) at the wrong level may create distortions in the relative price of traded to non-traded goods, which can generate incorrect signals to economic agents and result in greater economic instability. This essentially results in the suboptimal allocation of resources across the various sectors of the economy. Furthermore, sustained REER overvaluations constitute an early warning indicator of possible currency crashes (Krugman 1979; Frankel and Rose 1996; Kaminsky and Reinhart 1999). Furthermore, overvaluations have also been empirically found to have a negative impact on growth in the literature. Though this seems to be a long way off for the Trinidad and Tobago economy given its relatively large buffer of foreign reserves and a still healthy position of 9.7 months of import cover as of 2017, this can easily dissipate in the absence of greater exchange rate flexibility as noted by the IMF. Specifically, the IMF report noted that in the absence of greater exchange rate flexibility the country's healthy external reserve position of 10.9 months of import cover as of July 2016 could steadily deteriorate to under $3 \frac{1}{2}$ months by 2021 .

The question now arises: Is the Trinidad and Tobago currency really overvalued and to the extent outlined in the IMF Article IV report for 2016 for the T\&T economy? In this paper, we focus our attention on a discussion regarding the issue of currency misalignment in the T\&T economy for the period 1960 to 2016. We empirically examine T\&T's exchange rate misalignments for the period 1960 to 2016 as it deviates away from its equilibrium long run fundamentals. This study utilizes the ARDL approach for assessing cointegration, i.e., to assess whether a long-run relation exists amongst the real exchange rate and its fundamentals, which was proposed by Pesaran and Smith (1995) and further developed by Pesaran et al. (2001). The paper also examines the impact of exchange rate misalignments on economic growth for the Trinidad and Tobago economy. We also examine whether these effects are linear or non-linear; by testing the theoretical and empirical notion that an overvaluation is harmful to economic growth whilst an undervaluation is beneficial to economic growth.

The paper is unique as it is the first paper, to the best of our knowledge, to empirically examine T\&T's real effective exchange rate misalignments and its potential impact on economic growth. Studies

2 This recovery however, is in no comparison to the prices enjoyed by oil producing countries (OPC's) over the last decade, adding to severe macro-economic pressures currently being face by most of these OPC's. 
examining the impact of exchange rate misalignments, specifically the impact of overvaluations and undervaluations on economic growth for net oil exporters are sparse. The contribution of this study to the existing literature is three-fold. From our review of the literature, to the best of our knowledge, this is the first empirical paper that addresses the impact of exchange rate misalignments (both overvaluations and undervaluations) on economic growth on such a country classification. The studies cited in this paper as well as other studies conducted for net oil exporters in the literature focus mainly on the effect of oil prices on the REER, i.e., the Dutch disease effect. Secondly, the paper provides useful policy implications in relation to the current size and extent of T\&T's exchange rate misalignment. In particular, it provides contrasting results in relation to those found by the IMF Article IV 2016 for the T\&T economy, which as highlighted above, found the currency to be substantially overvalued in the range of 21.3 to $50 \%$, whereas this paper finds an overvaluation of $9.5 \%$ and $7.1 \%$ for the years 2015 and 2016 respectively. The differences in these findings can have serious policy implications if policy makers choose to utilize the IMF findings. Third, the paper presents results that are not in line with the current empirical literature whereby we find that both undervaluations and overvaluations impact negatively on growth in T\&T economy, which contradicts the results of recent empirical literature (see, for example, Rodrik (2008)).

In this regard, the rest of this paper is organized in the following way. In Section 2 of the paper, we review the evolution of the exchange rate in the Trinidad and Tobago economy. Section 3 provides a comprehensive review of the literature on the relationship between real exchange rate misalignments and economic growth. Section 4 outlines the methodology used in the paper, and briefly outlines the data and their respective sources used in the study. Section 5 provides a discussion on the empirical results obtained, whilst Section 6 estimates the exchange rate misalignments and examines its impact on economic growth in the Trinidad and Tobago economy. Lastly, Section 7 concludes and provides key policy recommendations.

\section{Evolution of the Exchange Rate Regime in Trinidad and Tobago}

In discussing currency valuation for Trinidad and Tobago, the natural point of departure for this discussion is the country's dependence on oil and natural gas exports. Trinidad and Tobago has been a significant exporter of oil for many decades and more recently a major producer of natural gas ${ }^{3}$. The volatility in prices for these natural resources impacts significantly on T\&T's economy, and by extension its exchange rate value as well. During the 1960s up to the early 1990s, T\&T adopted a fixed exchange rate regime, where it was pegged to the US\$ before shifting to a managed float regime from the 13th of April 1993. During the period 1974 and 1982, T\&T benefitted immensely from positive oil shocks which led to economic boom conditions in Trinidad and Tobago. Real GDP growth for the period averaged $4.60 \%$ whilst foreign exchange reserves climbed from TT\$768.3 million in 1974 to TT $\$ 7.16$ billion in 1982, peaking at TT\$7.69 billion in 1981. Along with this, government expenditures rose sharply and there was a commensurate fall in unemployment. The unprecedented boom was followed by an adverse movement in the country's terms of trade which was precipitated by falling oil prices from a peak of US $\$ 39.60$ per barrel in 1981 to less than US\$15 in 1986. This led to declining government revenues and mounting fiscal deficits which grew from 1.4 percent to $13.1 \%$ of GDP in 1983. The reaction of the Government of the Republic of Trinidad and Tobago (GORTT) was to control imports rather than devalue the local currency. Consequently, there was a system of ex ante Central Bank controls over imports and the implementation of a wide array of tariffs, taxes, and subsidies.

In 1986, when international oil prices fell to less than US\$15 per barrel, Trinidad and Tobago experienced a precipitous fall in foreign exchange reserves. Reserves fell to the equivalent of less than

3 Commercial oil production in Trinidad and Tobago began in 1908; however, the first well was drilled in 1857 by the Merrimac Company. In 1999, the commissioning of the first of four Atlantic LNG trains, led to a shift in the economy from being highly oil dependent, to being heavily dependent on natural gas as well, according to Hosein et al. (2017). 
two months of import cover. Between 1982 and 1987, earnings from the petroleum sector fell by almost $50 \%$ and the rate of unemployment doubled from 10 to $22 \%$. Realizing that approaching the IMF was inevitable in order to finance the growing fiscal deficit, the government then further devalued the currency to a unified rate of US\$1.00 $=\mathrm{TT} \$ 3.60$. However, the decline in the economic standing of Trinidad and Tobago eventually led to the signing of a stand-by agreement with the IMF in 1987 with an additional agreement signed in 1990.

The design of the stabilization program emphasized tax reform, making the exchange rate more competitive, liberalizing the trade regime, increasing privatization, and reducing the external account and fiscal deficits. It was thought that these policies would create an environment conducive to increasing production and exports. Consequently, the government reduced the public sector wage bill by $10 \%$, privatized and liquidated parts of state-owned enterprises, and introduced the $15 \%$ value added tax (VAT) covering all goods and services except for exports and some basic commodities. The government also introduced selective credit controls, reserve requirements, and limited open market operation to control the availability of credit. In 1988, faced with even further declines in petroleum prices and a significant cluster of external debt service payments, the government adopted a more comprehensive program which included a $15 \%$ devaluation in the currency which led to a cumulative depreciation in real effective terms of over $40 \%$ since the beginning of 1985 .

Fast forward to 1993, the government decided to abolish controls on the current and capital transactions in favour of having the value of the Trinidad and Tobago dollar be determined within the context of an interbank market whose major players would have then been the authorized foreign exchange dealers. Since then, the value of the Trinidad and Tobago dollar appreciates or depreciates in response to changes in supply and demand conditions in the foreign exchange market and the intervention policy of the Bank; therefore, in practice, the foreign exchange system is a managed float. This led to the classification of Trinidad and Tobago as a de facto floating exchange rate regime by the International Monetary Fund. Under the free float system, the central bank would adopt a passive stance and let the exchange rate be determined freely in the foreign exchange markets. In this instance, the central bank's non-intervention in the foreign exchange markets means that the balance of payments and reserves transactions are zero ${ }^{4}$. Therefore, under a managed float, the official reserves are not equal to zero. In looking at Figure 1, we see that the managed float exchange rate regime provided stability in the currency value which should have been reflected in price stability in Trinidad and Tobago.

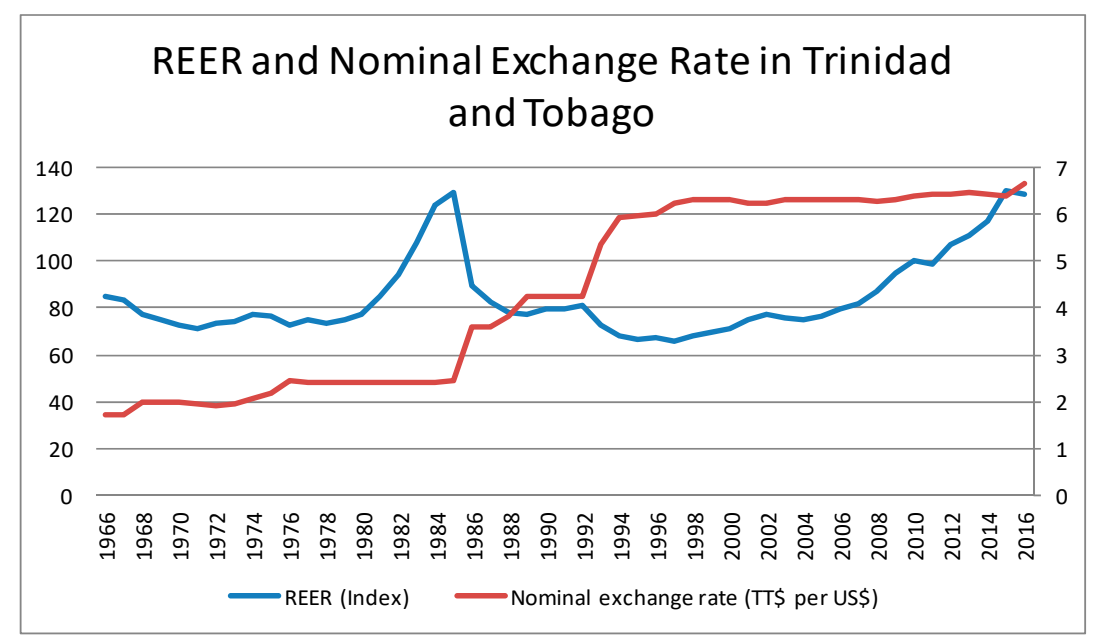

Figure 1. Displaying the Real Effective Exchange Rate and Nominal Exchange Rate in Trinidad and Tobago for the period 1966 to 2016. Source: World Bank, World Development Indicators. 


\section{Literature Review: The Relationship between Real Exchange Rate Misalignments and Economic Growth}

This section of the paper presents a brief overview of the evidence in the literature on the link between REER misalignments and economic growth. Johnson et al. (2006) argues that the exchange rate policy acts as a "lever for growth" even in countries with relatively weak institutions. According to Habib et al. (2017), whilst politicians are often convinced that a lower exchange rate will spur economic growth, economists on the other hand are generally skeptical that the relative price of two currencies may be a fundamental driver of economic growth over the long run. However, several studies have put forth theoretical arguments in favour of this relationship, see studies done by Rodrik (2008), Aizenman and Lee (2010), Di Nino et al. (2011), McLeod and Mileva (2011) and Glüzmann et al. (2012). Whilst on the other hand, there has been a plethora of empirical literature in recent times confirming this relationship, see Aguirre and Calderón (2005), Rodrik (2008), Rapetti et al. (2012), Béreau et al. (2012) and Missio et al. (2015). Furthermore, recent empirical literature surrounding this topic has highlighted that there exists a non-linear effect of currency or exchange rate misalignment on economic growth (see Aguirre and Calderón (2005)).

The approach outlined in (Krueger 1983; Edwards 1989; Williamson 1990; Berg and Miao 2010), which is often referred to as the "Washington consensus view", holds that the value of the exchange rate should be determined by both internal and external balances. According to Mbaye (2013), deviations away from this equilibrium level, i.e., exchange rate misalignments are associated with macroeconomic disequilibrium irrespective of the direction of the misalignment. In sum, under this view, both undervaluations and overvaluations are argued to be harmful to growth. An overvalued currency is associated with a loss of external competitiveness, a squeeze on the tradable sector and increased likelihood of balance of payments and currency crises (see for example Cottani et al. 1990; Ghura and Grennes 1993; Loayza et al. 2005; Krugman 1979; Frankel and Rose 1996; Kaminsky and Reinhart 1999). Furthermore, Rodrik (2008) argues that an overvaluation is associated with foreign currency shortages, rent-seeking and corruption, unsustainably large current account deficits, balance of payment crises, and stop-and-go macroeconomic cycles, all of which are damaging to economic growth.

Conversely, undervaluations are discredited on the grounds that it could produce unnecessary inflationary pressures and also limit the resources available for domestic investment, and for this reason curb the growth of supply-side potential according to Williamson (1990). Furthermore, as pointed out by Nunnenkamp and Schweickert (1990), cost push inflation can occur in the export sector and even diminish the competitiveness of a country's exports if the country's export sector relies heavily on imported inputs. Krugman and Taylor (1978) note that production may suffer on account of the fact that imported inputs get costlier following a real devaluation.

However, recent empirical studies proffer that overvaluations should be avoided as they impact negatively on economic growth whilst an undervaluation impacts positively on growth. The majority of the recent literature points to the latter, i.e., an undervalued real exchange rate on account of the fact that it leads to increases in private investment in the traded goods sector. An undervalued exchange rate affects growth through two main transmission channels, namely the "capital accumulation channel" and the "total factor productivity (TFP) growth channel" according to Mbaye (2013). Under the "capital accumulation channel" an undervalued exchange rate impacts positively on economic growth through an increase in the stock of capital in the economy. This channel operates exclusively in the tradable goods sector whose share in GDP increases, (see Rodrik (2008)); while a second string of literature posits that the stock of capital increases through the expansion of overall savings and investment (Levy-Yeyati and Sturzenegger 2007; Bhalla 2007). Levy-Yeyati and Sturzenegger (2007) show that depreciated exchange rates appear to induce higher growth, but this effect works largely through the deepening of domestic savings and capital accumulation, rather than through import substitution or export booms as argued by the mercantilist view. In other words, depreciated real 
exchange rates tend to increase the domestic saving rate, and a higher saving rate in turn stimulates growth by increasing the rate of capital accumulation.

The second transmission channel on the other hand places the structure of domestic production at the core of the analysis. An undervalued exchange rate results in an increase in the prices of tradable goods relative to non-tradables, thereby resulting in increased profitability of the tradable goods sector. This results in a shift in production away from non-tradables to tradable goods which are assumed to be characterized by a higher level of productivity, with the end result being an overall increase in productivity in the economy, Mbaye (2013) ${ }^{5}$. "Such economy-wide productivity improvement ultimately fosters growth" Mbaye (2013, p. 3).

Di Nino et al. (2011) concluded that undervaluation can lead to increased export activity, particularly in highly productive sectors. In such an instance, there is an incentive to maintain the relative price of traded goods high enough to make it attractive to shift resources into their production. In Aizenman and Lee (2010), McLeod and Mileva (2011) and Benigno et al. (2015), the existence of learning by doing externalities to individual firms in the traded goods sector, calls for a weak exchange rate, i.e., an undervalued exchange rate to support the production of tradables. In these models, exchange rate undervaluation acts as a subsidy to the more efficient tradables sector according to Habib et al. (2017).

McLeod and Mileva (2011) were able to show through a two-sector open economy growth model that a combination of "learning by doing" in the traded goods sector along with a weak REER which acts as a policy lever that moves workers into traded goods production faster, can lead to a surge in total factor productivity (TFP) growth ${ }^{6}$. Specifically, their findings indicate that a $10 \%$ real depreciation of the exchange rate leads to a $0.2 \%$ increase in average annual TFP growth rate. Whilst results generated from a dynamic panel model indicate that the impact can be twice as large, ranging between $0.3 \%$ and $0.5 \%{ }^{7}$. Empirical results derived in Mbaye (2013) offer strong support to the TFP growth channel; whereby a 10\% increase in undervaluation enhances growth on average by $0.14 \%$ via an improvement in productivity ${ }^{8}$. Conversely, a $1 \%$ increase in overvaluation is associated with a $0.021 \%$ contraction in growth on average.

Rodrik (2008) posits that a weak real exchange rate compensates for institutional weaknesses and market failures which lead to underinvestment in the traded goods sector in developing countries. Under both circumstances, Rodrik notes that an increase in the relative price of traded goods (i.e., through the weakening of the real exchange rate) "acts as a second-best mechanism to partly alleviate the relevant distortion, foster desirable structural change, and spur growth" (p. 370). A policy measure of this nature encourages structural change, enhances export capacities and improves economic growth by shifting the internal terms of trade in favour of the tradable sector Rodrik (2009) Freund and Pierola (2008). Rodrik provides evidence via the use of a simple growth model for a small open economy, to support the fact that both institutional weaknesses and market failures (distortions) affect the traded sector more than they affect the non-traded sector. Rodrik (2009) is able to demonstrate through his model, that when the distortion in the traded sector is larger than in the non-traded sector, the traded sector is too small in equilibrium and hence a weakening of the exchange rate through a policy or other exogenous shock will have a growth-promoting effect.

5 For atheoretical derivation of this channel, please see the work of Matsuyama (1992), Aizenman and Lee (2010) and McLeod and Mileva (2011). McLeod and Mileva (2011) show that a combination of "learning by doing" in the traded goods sector and a policy lever, such as the REER, which moves workers into traded goods production faster, can lead to a surge in total factor productivity (TFP) growth and as a result overall economic growth. The authors adopt a model that is similar to Matsuyama (1992) two-sector open economy growth model to derive these results.

6 Mbaye (2013) defines the "learning by doing effect" as a firm's capability to improve their productivity as they accumulate experience in the production process, i.e., productivity gains are typically achieved through practice and self-perfection.

7 The panel model estimated consisted of 58 developing countries and spanned the period 1975-2004.

8 The analysis is conducted on a panel of 72 countries over the period 1970 to 2008. 
Aguirre and Calderón (2005) provide empirical evidence on the relationship between exchange rate misalignments and economic growth. Specifically, the authors find that real exchange rate misalignment hinders growth, the larger the size of the misalignments, the larger the decline in growth. Several studies have provided empirical evidence showing that an overvaluation is associated with a negative impact on growth, (see Dollar 1992; Razin and Collins 1999; Aguirre and Calderón 2005; Rodrik 2008; Elbadawi et al. 2012; Mbaye 2013) among many others. Conversely, the empirical literature is replete with evidence that a weak or undervalued exchange rate impacts positively on economic growth, in particular developing economies, (see Aguirre and Calderón 2005; Rodrik 2008; Elbadawi et al. 2012; Mbaye 2013) among many others. Most empirical work continues to show that there is a positive correlation between weak real exchange rates and economic growth, (see Habib et al. 2017).

Dollar (1992) empirically illustrates that an overvalued exchange rate hampers economic growth. Conversely, whilst an undervalued exchange rate can spur economic growth, if the exchange rate is grossly undervalued this in turn can harm growth whereas modest undervaluation enhances growth prospects, (see Aguirre and Calderón 2005). Aguirre and Calderón (2005) implemented a generalized method of moments (GMM) model for dynamic models of panel data developed by Arellano and Bond (1991) and Arellano and Bover (1995). The study consisted of a sample of 60 countries and the analysis spanned the time period 1965-2003. Specifically, the authors find that a small undervaluation of up to $12 \%$ is associated with a positive growth response. The authors also calculate the effect an additional 5\% real undervaluation has on economic growth for countries with differing initial levels of exchange rate undervaluation. The results highlight that for a country with an initial undervaluation of $10 \%$, a further $5 \%$ increase to the undervaluation of the exchange rate would result in a negligible increase in economic growth of only four basis points per year. However, an increase in the degree of real undervaluation from 20 to $25 \%$ would reduce the growth rate by 43 basis points per year, while a further increase in the undervaluation from 30 to $35 \%$ leads to an even more severe decline in economic growth (approximately $0.9 \%$ per year).

\section{Model and Data}

This study seeks to primarily examine T\&T's exchange rate misalignments over the period 1960 to 2016, and its impact on economic growth. The common thread in the literature to examine exchange rate misalignments is to estimate its deviations away from its equilibrium component utilizing a long run model, (see Aguirre and Calderón 2005; Elbadawi et al. 2012). Montiel (1999) argued that the long run equilibrium real exchange rate emerges from macroeconomic equilibrium in an economy where policy and exogenous variables are sustainable in the long run. Furthermore, an understanding of the fundamental factors that affect or influence a country's exchange rate is vital. A proper understanding of those factors that influence an economies exchange rate, i.e., those factors that have an effect on the long run equilibrium exchange rate is key for policy makers on account of the fact that previous research has shown that maintaining REER close to its equilibrium rate is key to ensure the growth and stability of the economy along with maintaining the overall external competitiveness of the economy, (see Elbadawi and Helleiner 2005; Aguirre and Calderón 2005). Moreover, as noted earlier in the study, not only avoiding overvaluation is necessary for growth but a mild undervaluation may be good for growth, (see Aguirre and Calderón 2005).

Following several studies in the literature, we model the fundamentals of T\&T's equilibrium exchange rate for the period 1960 to 2016 using the following econometric specification:

$$
\ln R E E R_{t}=\alpha+\beta_{1} \ln Y_{t}+\beta_{2} \ln G_{t}+\beta_{3} \ln N F A_{t}+\beta_{4} \ln C R P_{t}+\beta_{5} \ln \operatorname{OILP}_{t}+\beta_{6} \ln R E S E R V E S_{t}+\varepsilon_{t}
$$

where REER is the real effective exchange rate index; $Y$ is real GDP per capita in US dollars 2010; G is government consumption expenditure as a percent of GDP; NFA is net foreign assets as a percentage of GDP; CRP is domestic credit to the private sector as a percent of GDP; OILP is the real oil price; 
RESERVES is total reserves as a percentage of GDP and $\alpha$ and $\varepsilon$ are the constant and error term respectively. All variables are taken from the World Bank's World Development Indicators (WDI) online database with the exception of REER which is taken from Darvas (2012).

To estimate Equation (1), we implement the Autoregressive Distributed Lag (ARDL) approach to assessing cointegration, i.e., whether a long run relation exists amongst our variables, which was introduced by Pesaran and Smith (1995) and further developed by Pesaran et al. (2001). We choose to utilize this model over other cointegration tests such as the Johansen cointegration test given the number of advantages of using the ARDL approach, which are outlined by Pesaran et al. (2001), Acaravci and Ozturk (2012) and Gasmi and Laourari (2017). A major benefit to utilizing this model is that it can be applied irrespective of whether the series under investigation are stationary at I(0) or $\mathrm{I}(1)$ or a mixture of both. In contrast to the Johansen cointegration procedure, the ARDL approach can accommodate different orders of integration of the variables and pre-testing for a unit root is only necessary to ensure there are no I(2) variables, (Salim et al. 2015; Gasmi and Laourari 2017; Nguyen 2017). Another advantage of the ARDL model is the fact that it takes into account the error correction model, which enables the model to simultaneously estimate both short and long-run coefficients, (see Pesaran et al. 2001; López Villavicencio and Bara 2008; Sami and Kreishan 2012). As such, the ARDL model of Equation (1) is outlined below:

$$
\begin{gathered}
\Delta \ln R E E R_{t}=\alpha+\beta_{1} \ln R E E R_{t-1}+\beta_{2} \ln Y_{t-1}+\beta_{3} \ln G_{t-1}+\beta_{4} \ln N F A_{t-1}+\beta_{5} \ln C R P_{t-1}+ \\
\beta_{6} \ln \operatorname{IILP}_{t-1}+\beta_{7} \ln R E S E R V E S_{t-1}+\sum_{i=1}^{p} \omega_{i} \Delta \ln R E E R_{t-i}+\sum_{i=1}^{p} \lambda_{i} \Delta \ln Y_{t-i}+\sum_{i=1}^{p} \gamma_{i} \Delta \ln G_{t-i}+ \\
\sum_{i=1}^{p} \theta_{i} \Delta \ln N F A_{t-i}+\sum_{i=1}^{p} \mu_{i} \Delta \ln C R P_{t-i}+\sum_{i=1}^{p} \pi_{i} \Delta \ln O I L P_{t-i}+\sum_{i=1}^{p} \sigma_{i} \Delta \ln R E S E R V E S_{t-i}+\varepsilon_{t}
\end{gathered}
$$

where $\Delta$ is the difference operator, $\alpha$ and $\varepsilon$ are the constant and error term respectively and $p$ is the optimal lag length which will be determined using Akaike Information Criteria (AIC) and Schwartz Information criteria (SIC) respectively. The coefficients on the differenced terms represent the short run relationships, whereas, the coefficients on the level terms, i.e., $\beta_{1}$ to $\beta_{7}$ correspond to the long-run relationships.

To assess whether there exists a long-run relation amongst our variables, i.e., whether there exists a cointegrating relation, the ARDL bound test is implemented. If the calculated F-statistic of the coefficients on the variables in levels is greater than the critical value bounds provided by Pesaran et al. (2001), we conclude that there is cointegration among our variables. On the other hand, if the F-statistic falls between the critical value bounds, the results are inconclusive, or, if the $F$-statistic is less than the critical value bounds, there is no evidence of cointegration among the variables. "However, if the Wald or F-statistic falls inside these bounds, inference is inconclusive and knowledge of the order of the integration of the underlying variables is required before conclusive inferences can be made", Pesaran et al. (2001, p. 290). When the order of integration of the variables under consideration is known and all the variables are integrated of the order of one, the decision is made based on the upper bound, whilst if all the variables under control are integrated of the order of zero $\mathrm{I}(0)$, the decision is made based on the lower bound, Pesaran et al. (2001).

In this study, due to data limitations, we are forced to utilize a small sample size of 56 observations. However, as pointed out by Narayan (2005), the upper and lower critical values of the F-distribution generated by Pesaran and Pesaran (1997) and Pesaran et al. (2001) were based on large sample sizes of 500 and 1000, as well as 20,000 and 40,000 replications, respectively. As such, Narayan (2004) and Narayan (2005) argued that the critical values generated by Pesaran and Pesaran (1997) and Pesaran et al. (2001) are not applicable to small sample sizes. Narayan (2004) compared the critical values generated for 31 observations and 4 regressors with the critical values reported in Pesaran et al. (2001) and found that the upper bound critical value at the 5\% significance level is 4.13 while the corresponding critical value for 1000 observations is 3.49 , which is $18.3 \%$ lower than the critical value for 31 observations. This along with the small sample size of 43 and 47 observations respectively in this present study led Narayan (2005) to calculate critical values for 
sample sizes ranging from 30 to 80 observations $^{9}$. As such, in this paper we also utilize the critical values generated by Narayan (2005) as a small sample size correction in order to ensure robustness of our cointegration results.

At this stage, we discuss the a priori expectations between the dependent and each of the independent variables. The literature highlights that an increase in government consumption can have one of two effects on the real exchange rate. This effect on the equilibrium real exchange rate depends on the composition of the consumption expenditure between tradable goods and non-tradable goods, (see Ibrahim 2016). An increase in government consumption can either lead to an appreciation (positive sign) or depreciation (negative sign) of the exchange rate depending on whether this increased consumption is biased towards non-tradables or tradables respectively, (see Edwards 1989; Doroodian et al. 2002; Naseem et al. 2009; Wondemu and Potts 2016).

Rodrik (2008) and Acosta et al. (2009) concluded that as GDP increases, the real exchange rate appreciates; hence we expect a positive sign for the GDP coefficient. Similarly to Rodrik (2008), we regress the real exchange rate against the per capita GDP to account for the Balassa-Samuelson effect. The reserves variable is expected to carry a negative sign, which suggests that any increases or accumulation of foreign exchange reserves will entail a depreciation of the exchange rate in order for the economy to be on its sustainable equilibrium level, (see Wondemu and Potts 2016; Habib et al. 2017). In regards to net foreign assets, Mariano et al. 2016 state that the accumulation of net foreign assets will lead to an appreciation (positive sign) of the exchange rate. Excessive credit to the private sector would boost domestic demand, worsen the CA, and appreciate (positive sign) the real exchange rate.

The a priori expectation is that the equilibrium REER will be more appreciated with higher terms of trade (TOT), (see Elbadawi et al. 2012; Doroodian et al. 2002). Given T\&T's large dependence on energy exports, which accounts for, on average, over $80 \%$ of the country's total merchandise exports, we proxy TOT using the oil price. Beckmann and Czudaj (2013) expect that during periods of increased oil prices that the currencies of oil-exporting countries will appreciate as wealth is transferred to the oil exporting economies (in US dollar terms) on account of the fact that it is reflected as an improvement in exports and the current account balance in domestic currency terms. Koranchelian (2005) and Zalduendo (2006) examine the impact of oil price on the real exchange rate in two oil exporters, Algeria and Venezuela, respectively. Both authors conclude that the real oil price has an impact on the real exchange rate for both countries. Koranchelian (2005) finds that a $1 \%$ increase in the real oil price is associated with an appreciation of the REER of about $0.2 \%$ in the Algerian economy, whilst Zalduendo (2006) finds that a 1\% increase in oil prices has almost a one-to-one effect on the real effective exchange rate (i.e., a $1 \frac{1}{4} \%$ appreciation) in the Venezuelan economy.

\section{Discussion and Analysis}

\section{ARDL Results}

As a preliminary step, we investigate the unit root properties of each of the respective series employed in the study. As noted earlier, the ARDL approach only requires pre-testing of the unit root properties of the time series in order to ensure there are no variables integrated of the order two, i.e., I(2) or higher. We employ the use of two standard unit root tests; namely the Augmented Dickey-Fuller test (ADF) and the Phillips-Perron test (PP). Table 1 summarizes the results of both unit root tests respectively. All variables are generally found to be I(1)'s and thus we proceed to estimating Equation (2) using the ARDL approach.

9 The critical values calculated can be found in the appendix of the paper. 
Table 1. Results generated by both the Augmented Dickey-Fuller (ADF) and Phillips-Perron (PP) Unit Root Tests.

\begin{tabular}{|c|c|c|c|c|c|c|c|c|}
\hline \multirow{3}{*}{ Variables } & \multicolumn{4}{|c|}{ ADF Test } & \multicolumn{4}{|c|}{ PP Test } \\
\hline & \multicolumn{2}{|c|}{ Level } & \multicolumn{2}{|c|}{ First Difference } & \multicolumn{2}{|c|}{ Level } & \multicolumn{2}{|c|}{ First Difference } \\
\hline & I & I\&T & I & $I \& T$ & I & I\&T & I & I\&T \\
\hline LREER & -0.27 & -1.27 & $-6.42^{* * *}$ & $-6.52^{* * *}$ & -0.56 & -1.54 & $-6.42 * * *$ & $-6.52 * * *$ \\
\hline LY & -0.82 & -1.72 & $-3.76^{* * *}$ & $-3.73^{* *}$ & -0.97 & -1.59 & $-3.71^{* * *}$ & $-3.68^{* *}$ \\
\hline LG & $-2.66 *$ & -2.62 & $-8.30^{* * *}$ & $-8.22 * * *$ & $-2.64 *$ & -2.59 & $-8.51 * * *$ & $-8.42^{* * *}$ \\
\hline LNFA & $-3.05^{* *}$ & $-3.87^{* *}$ & $-9.23^{* * *}$ & $-9.16^{* * *}$ & $-2.90 *$ & $-3.81 * *$ & $-10.32 * * *$ & $-10.26^{* * *}$ \\
\hline LCRP & -2.31 & -1.62 & $-7.35^{* * *}$ & $-7.75^{* * *}$ & -2.35 & -1.57 & $-7.35^{* * *}$ & $-7.92^{* * *}$ \\
\hline LOILP & -1.60 & -1.54 & $-6.54^{* * *}$ & $-6.54 * * *$ & -1.70 & -1.80 & $-6.53^{* * *}$ & $-6.53 * * *$ \\
\hline LRESERVES & -1.39 & -1.75 & $-6.11^{* * *}$ & $-6.06^{* * *}$ & -1.53 & -1.88 & $-6.04^{* * *}$ & $-5.98^{* * *}$ \\
\hline
\end{tabular}

$*, * *, * *$ denotes levels of significance at $10 \%, 5 \%$ and $1 \%$ respectively. Note: I denotes the unit root test with only an intercept term. I\&T denote the unit root test with both an intercept term and trend.

Prior to the estimation of Equation (2) using the ARDL approach, we must first determine the optimal lag length for the ARDL model. Correct specification of the lag length to be employed is pivotal, on account of the sensitivity of the bounds tests to the lags chosen and by extension finding a cointegrating relationship between our variables. As noted by Pesaran et al. (2001), there is a delicate balance between choosing a lag order that is sufficiently large in order to mitigate the residual serial correlation problem and, at the same time, sufficiently small so that the conditional error correction model (ECM) is not unduly over-parameterized. The latter is particularly important in this study, given the limited time series data which are available. To determine the appropriate lag length to be employed, Equation (1) is estimated using a maximum of three (3) lags given the small sample size. Both the Akaike Information Criteria (AIC) and the Schwarz Bayesian Information Criteria (SBIC) tests are employed to determine the optimal lag length. However, in small sample cases, it is advisable to rely on the SBIC criterion (Pesaran and Shin 1999; Fatai et al. 2003). The optimal ARDL specification is found to be $(1,2,0,2,3,1,3)$.

Based on the above ARDL specification, the results of the ARDL bounds test is presented in Table 2 below. The F-statistic exceeds the upper bound of both the critical values generated by Pesaran et al. (2001) and Narayan (2005) at all conventional levels of statistical significance, which signifies that there does in fact exist a cointegrating relationship amongst the REER and its fundamentals outlined in Equation (1).

Table 2. ARDL Bounds Test of Cointegration.

\begin{tabular}{ccccc}
\hline & \multicolumn{2}{c}{ Pesaran et al. (2001) } & \multicolumn{2}{c}{ Narayan (2005) $^{\mathbf{b}}$} \\
\hline At the 1\% significance level: & 3.15 & 4.43 & 3.53 & 5.08 \\
At the 5\% significance level: & 2.45 & 3.61 & 2.64 & 3.94 \\
At the 10\% significance level: & 2.12 & 3.23 & 2.25 & 3.44 \\
Calculated F-statistic & \multicolumn{2}{c}{$5.19^{* * *}$} & \multicolumn{2}{c}{$5.19^{* * *}$}
\end{tabular}

Note: ${ }^{a}$ shows lower and upper bound critical values for Bounds test derived by Pesaran et al. (2001). ${ }^{\mathrm{b}}$ shows lower and upper bound critical values for Bounds test proposed by Narayan (2005), which corresponds to the 60 observations case. ${ }^{*}, * *, * *$ denotes levels of significance at $10 \%, 5 \%$ and $1 \%$ respectively.

Having found a cointegrating relationship, the results from the ARDL model along with the corresponding diagnostic tests are as presented in Table 3 below.

The results of the ARDL model highlight that all of the independent variables with the exception of credit to the private sector have the expected sign. Although credit to the private sector carries the wrong expected sign, it is not statistically significantly different from zero up to the $10 \%$ level of statistical significance. We find a strong Balassa-Samuelson effect for the T\&T economy, whereby a $1 \%$ increase in output results in an appreciation of REER by $0.59 \%$. Government consumption also leads to an appreciation of the REER in the T\&T economy, whereby a $1 \%$ increase in government consumption 
results in a $0.41 \%$ appreciation of the REER, although not significant up to the $10 \%$ level of statistical significance. This result is in line with economic theory, highlighting that government consumption in the T\&T economy has been highly geared towards expenditure on non-tradables. Both the magnitude of the signs may need to be examined with care. As expected, the real oil price has a positive effect on the REER, i.e., a $1 \%$ rise in oil prices results in a $0.22 \%$ appreciation in the REER in the T\&T economy ${ }^{10}$. A $1 \%$ increase in reserves results in a depreciation of the REER by $0.3 \%$, whilst a $1 \%$ increase in net foreign assets to GDP results in a $0.18 \%$ appreciation of the REER.

Table 3. ARDL estimation results.

\begin{tabular}{ccccc}
\hline \multicolumn{5}{c}{ Panel A: Estimated Long-Run Coefficients } \\
\hline Variables & Coefficient & Std. Error & $\boldsymbol{t}$-Statistic & Probability \\
\hline LY & 0.59 & 0.14 & 4.32 & 0.00 \\
LG & 0.41 & 0.26 & 1.57 & 0.13 \\
LCRP & -0.13 & 0.09 & -1.42 & 0.16 \\
LNFA & 0.18 & 0.07 & 2.56 & 0.02 \\
LOILP & 0.22 & 0.10 & 2.21 & 0.03 \\
LRESERVES & -0.30 & 0.11 & -2.66 & 0.01 \\
C & -1.90 & 1.53 & -1.24 & 0.22 \\
ECT & -0.39 & 0.10 & 3.78 & 0.00 \\
\hline
\end{tabular}

Panel B: Residuals Diagnostics Tests Results

$$
\begin{gathered}
\mathrm{JB}_{\mathrm{N}}=54.35[0.00] \\
\chi^{2} \mathrm{ARCH}(4)=1.63[0.80] \\
\chi^{2} \mathrm{SC}(4)=2.27[0.69] \\
\mathrm{F}_{\mathrm{FF}}(2,33)=2.28[0.12]
\end{gathered}
$$

Note: The regression is based on the conditional error correction model (ECM) given by Equation (2) using an ARDL $(1,2,0,2,3,1,3)$ specification with the dependent variable LREER. $\mathrm{JB}_{\mathrm{N}}$ and $\mathrm{F}_{\mathrm{FF}}(2,33)$ denotes the Jarque-Bera Normality and the Ramsey RESET Test statistics to test the null hypotheses of the normal distribution and no functional form misspecification respectively whilst the $\chi^{2} \mathrm{ARCH}(4), \chi^{2} \mathrm{SC}(4)$ denotes the chi-squared statistics to test the null hypotheses of no heteroscedasticity and no serial correlation, respectively, in the residuals using the $\mathrm{ARCH}$ Heteroskedasticity test and the Breusch-Godfrey Serial Correlation LM Test respectively. The $p$-values are given in brackets. Source: Author's calculations using EViews.

The Speed of Adjustment coefficient, i.e., the coefficient on the error correction term (ECT) is negative and statistically significant at the $1 \%$ significance level, which is indicative of a stable long-run relationship between the real effective exchange rate and the right hand side variables in Equation (2). The negative sign indicates a move back towards equilibrium if there is a shock in the system. The results show that in the short run, deviations from our long-run equilibrium are corrected at roughly $39 \%$ every year. In other words, the REER is estimated to take on average a little over two and a half years to return to its equilibrium level following a shock in the system which can have negative impacts on the external competitiveness of the economy.

The final specification of the ARDL model successfully passes the residual diagnostics tests of the heteroscedasticity, autocorrelation or serial correlation tests and the Ramsey RESET misspecification test, which are highlighted in the lower part Table 3. The stability of the parameters in Equation (2) were assessed using the cumulative sum of the recursive residuals (CUSUM) and the cumulative sum of the squares of recursive residuals (CUSUMSQ) tests proposed by Brown et al. (1975), and are presented in Figures A1 and A2 respectively in the Appendix A. The CUSUM and CUSUMSQ tests implemented show that this estimated equilibrium model is dynamically and structurally stable at the five percent significance level, and the specification is stable towards the end of the period, which is desirable. Overall, the diagnostic tests all support that the long-run equations are robust.

10 A study by Hasanov et al. (2017) finds similar results. The authors find that a $1 \%$ increase in the real price of oil results in a $0.26 \%, 0.28 \%$ and a $0.56 \%$ appreciation of the real effective exchange rate for the Azerbaijan, Kazakhstan and Russian economies respectively. 


\section{Exchange Rate Misalignment}

Upon estimation of Equation (2), we estimate the exchange rate misalignments (REERmis) as the difference between the natural log of REER and the natural log of the estimated equilibrium real effective exchange rate (EREER). We follow the works of both Aguirre and Calderón (2005) and Elbadawi et al. (2012) and compute the EREER by feeding the estimated model with the permanent components of the fundamentals, i.e., we multiply the estimated coefficients generated by the ARDL for Equation (2) by the permanent values of the fundamentals. To estimate the permanent component of the fundamentals, we utilize the Hodrick-Prescott (HP) filter (1997) technique as suggested by Edwards (1989) and Alberola (2003) ${ }^{11}$. According to Elbadawi et al. $(2012$, p. 689) "these permanent components are characterized as sustainable levels and are, therefore, consistent with the concept of equilibrium". The results of the exchange rate misalignment are presented in Figure 2.

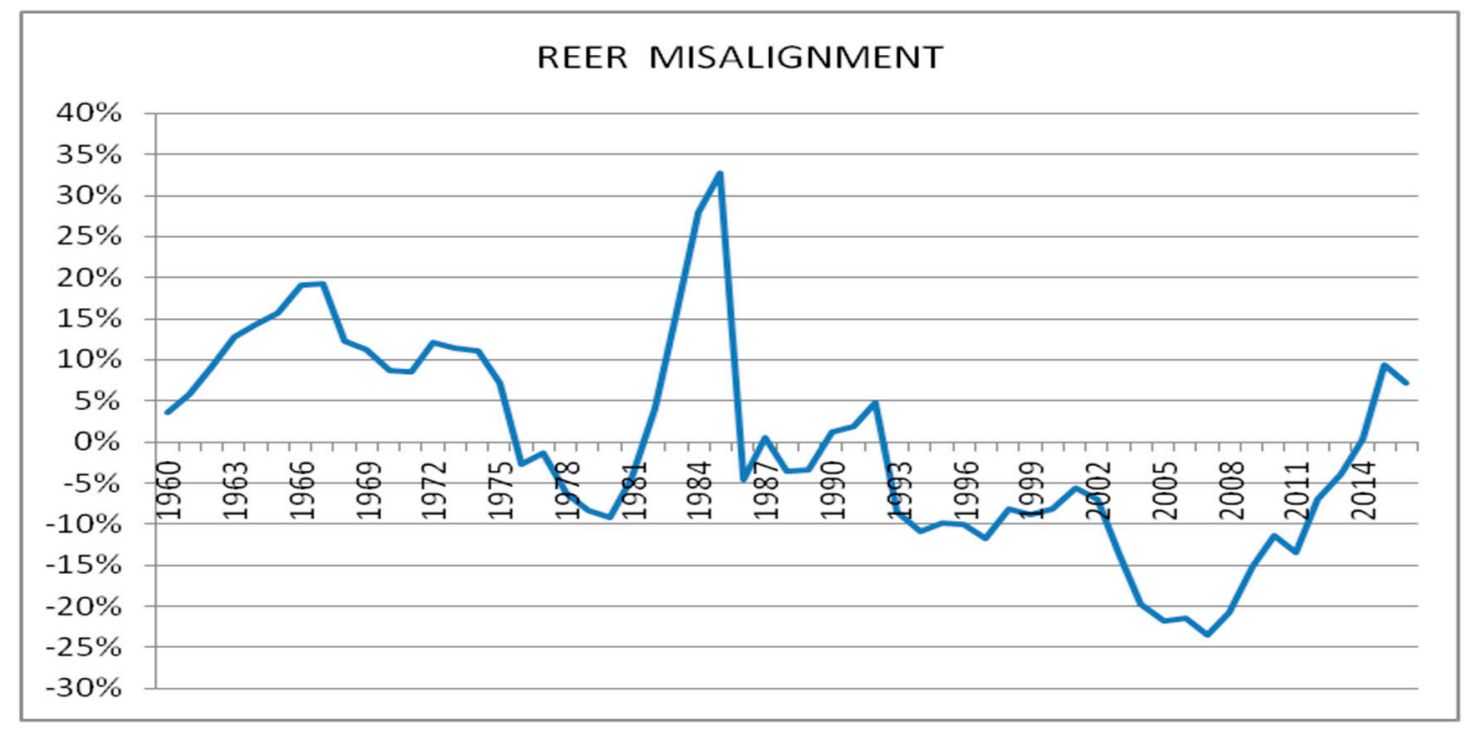

Figure 2. REER misalignment over the period 1960 to 2016 in the T\&T economy. Note: above zero line is an overvaluation.

Figure 2 depicts the extent of overvaluation (above zero in the vertical scale; i.e., depreciation pressures) and undervaluation (below zero in the vertical scale; i.e., appreciation pressures) for the T\&T economy for the period 1960 to 2016. Figure 2 illustrates that the REER had been significantly overvalued from the 1960s to mid-1970s, partly on account of the fixed or pegged nominal exchange rate system adopted in T\&T over this period. From 1967 onwards the exchange rate began to move back to equilibrium which can be attributed to several devaluations that took place. Figure 2 indicates that the real exchange rate was significantly overvalued in the period 1982 to 1985 , peaking at $32.73 \%$ in 1985 which may have been on account of the drastic decline in growth and foreign exchange reserves experienced in the T\&T economy during this time period. Real GDP growth for the period 1983 to 1985 averaged minus $6.73 \%$, with growth declining from $3.8 \%$ in 1982 to minus $10.31 \%$ in 1983 . Foreign reserves also declined rapidly in this period, falling from TT $\$ 7.16$ billion in 1982 to TT $\$ 3.58$ billion in $1985^{12}$.

Post-1985, there was a drastic devaluation of the currency which was much more drastic and severe as a result of the recessionary pressures on account of depressed oil prices. In 1986, when international oil prices fell to less than US\$15 per barrel, Trinidad and Tobago experienced a precipitous fall in

11 The HP filter is widely utilized in the literature to extract the long run or permanent component of a series. To estimate the permanent component, we utilize the smoothing parameter $\lambda$ of 100 outlined by Hodrick and Prescott (1997).

12 Foreign reserves declined further to 1.19 billion TT\$ in 1986 and by 1987 it had fallen to 304.1 million TT\$. 
foreign exchange reserves. The Trinidad and Tobago currency was devalued from TT $\$ 2.45$ to 1 US\$ in 1985 to TT\$3.60 to 1 US\$ in 1986. These factors outlined contributed significantly to the sharp decline of the equilibrium REER in the short space of one year, which saw the REER moving from being overvalued by $32.73 \%$ in 1985 to an undervaluation of $4.62 \%$ by 1986 . Fiscal adjustments and the implementation of the IMF package as outlined in Section 2 of the paper resulted in the exchange rate moving back to equilibrium in 1992.

However, in 1993, when the Central Bank of Trinidad and Tobago (CBTT) devalued the nominal exchange rate and shifted to a managed float regime, the REER was undervalued by $8.54 \%$. The exchange rate was further undervalued over the period 2002 to 2008, which was during the second oil boom which resulted in the T\&T economy experiencing rapid growth and development, in addition to building up a large stock of foreign reserves which grew from US $\$ 2$ billion in 2002 to US $\$ 10.6$ billion in 2008. The exchange rate has been overvalued since 2014, with the majority of this owing to the decline in oil prices which occurred in mid-2014 which subsequently also resulted in a decline in foreign reserves in the T\&T economy. This overvaluation can also be linked to the state's intervention which continues to maintain the nominal exchange rate at a relatively fixed level to the US dollar through the CBTT. Furthermore, real economic activity stalled in the T\&T economy, which recorded negative growth rates of $0.58 \%, 0.58 \%$ and $2.27 \%$ respectively for the years 2014,2015 and 2016 .

\subsection{The Relationship between Real Exchange Rate Misalignment and Economic Growth in TET}

In this section we seek to examine the impact of exchange rate misalignments on the growth performance of T\&T. Furthermore, we also test for non-linear effects by examining the impacts of overvaluations and undervaluations on economic growth. As noted earlier, the majority of the literature highlights that an overvalued exchange rate hampers or negatively affects economic growth whilst an undervalued exchange rate is generally thought of to be growth-enhancing in developing economies. However, we first examine the impact of real exchange rate movements on economic growth prior as a preliminary step in our analysis. In short, we aim to investigate the effects of appreciations (increases in the REER) and depreciations (decreases in REER) on economic growth in the Trinidad and Tobago economy which is susceptible to large appreciations due mainly to significant swings in oil prices (see Table 3 in Section 5). Other variables that were found to be positive and significant include output, government expenditure and net foreign assets; however, the volatility in these variables is not as pronounced as compared to oil prices in the Trinidad and Tobago economy.

Examining the impact that exchange rate movements have on economic growth is of particular importance in the case of T\&T given its large dependence on the energy sector, which can result in the economy experiencing Dutch Disease type effects. The term Dutch Disease was first used by the Economist Magazine in 1977 to describe Netherlands declining manufacturing sector as the Dutch Guilder appreciated and is formally outlined and documented in Corden and Neary (1982). In the early 1960s, the Dutch economy experienced an export boom that was initiated by massive gas discoveries that led to an appreciation of the Dutch Guilder, which led to an overall reduction in the competitiveness of the Dutch manufacturing and industrial sectors as the real exchange rate further appreciated. A Dutch Diseased economy also tends to result in a more service-based economy as activity in the non-tradable or services sector picks up due to the influx of foreign exchange in the domestic economy which increases prices and profitability within the sector. The data in Table A1 in the Appendix A highlights this taking place in the T\&T economy, as following windfall in the energy sector and a more gradual dependence on the energy sector, both manufacturing and agricultural output fell whilst the services sector as a share of GDP increased.

To examine the impact of real exchange rate movements on economic growth in the T\&T economy, we estimate the following model:

$$
\mathrm{Y}=\mathrm{f}(\mathrm{REER}, \text { Controls) }
$$

where $\mathrm{Y}$ is real GDP per capita growth, and the control variables include inflation (INFLATION), gross domestic savings (SAVINGS), trade openness defined as the sum of exports and imports over 
GDP (OPENESS), and credit to the private sector as a percent of GDP (CRP) ${ }^{13}$. The variable SAVINGS is deflated using the GDP deflator which was sourced from World Databank's World Development Indicators (WDI) in order to take into account the effects of inflation on the respective time series.

Table 4 highlights that an increase (appreciation) of the REER impacts negatively on growth whilst on the other hand a decrease (depreciation) of the REER impacts positively on economic growth in the T\&T economy. In particular, a $1 \%$ appreciation of the REER is associated with a $0.10 \%$ decline in economic growth. All coefficient signs are in line with our a priori expectation with the exception of the coefficient signs on trade openness and credit to the private sector, however, both are not statistically significant.

Table 4. REER movement and economic growth.

\begin{tabular}{ccccc}
\hline \multicolumn{5}{c}{ Panel A: Estimated OLS Coefficients } \\
\hline Variables & Coefficient & Std. Error & $\boldsymbol{t}$-Statistic & Probability \\
\hline LREER & -0.095 & 0.032 & -3.00 & 0.00 \\
DLOPENESS & -0.004 & 0.048 & -0.09 & 0.93 \\
DLSAVINGS & 0.024 & 0.028 & 0.86 & 0.40 \\
INFLATION & -0.004 & 0.001 & -3.41 & 0.00 \\
DLCRP & -0.080 & 0.051 & -1.57 & 0.12 \\
C & 5.090 & 0.145 & 35.16 & 0.00 \\
\hline
\end{tabular}

Panel B: Residuals Diagnostics Tests Results

$$
\begin{gathered}
\mathrm{JB}_{\mathrm{N}}=0.65[0.72] \\
\chi^{2} \mathrm{BPG}=2.77[0.74] \\
\chi^{2} \mathrm{SC}(2)=13.60[0.00] \\
\mathrm{F}_{\mathrm{FF}}(1,48)=0.58[0.45]
\end{gathered}
$$

Note: The dependent variable real GDP per capita growth. $\mathrm{JB}_{\mathrm{N}}$ and $\mathrm{F}_{\mathrm{FF}}$ denotes the Jarque-Bera Normality and the Ramsey RESET Test statistics to test the null hypotheses of the normal distribution and no functional form misspecification, respectively, whilst the $\chi^{2}$ BPG, $\chi^{2} S C(2)$ denotes the chi-squared statistics to test the null hypotheses of no heteroscedasticity and no serial correlation respectively in the residuals using the Breusch-Pagan-Godfrey Heteroskedasticity test and the Breusch-Godfrey Serial Correlation LM Test respectively. The $p$-values are given in brackets. Source: Author's calculations using EViews.

To examine the impact of exchange rate misalignments on economic growth in the T\&T economy, we follow the works of Aguirre and Calderón (2005), Elbadawi et al. (2012), Habib et al. (2017) and estimate the following model:

$$
\mathrm{Y}=\mathrm{f}(\text { REERmis, Controls })
$$

where REERmis is the real exchange rate misalignment variable estimated in Section 6 and the control variables are the same as in Equation (3).

The results from Table 5 highlight that real exchange rate misalignments impact negatively on economic growth in the T\&T economy. Specifically, a $1 \%$ increase in the misalignment is associated with a $-0.16 \%$ decline in economic growth in the T\&T economy.

13 All variables were sourced from World Bank's World Development Indicators (WDI) online database. 
Table 5. REER misalignment and economic growth.

\begin{tabular}{ccccc}
\hline \multicolumn{5}{c}{ Panel A: Estimated OLS Coefficients } \\
\hline Variables & Coefficient & Std. Error & $\boldsymbol{t}$-Statistic & Probability \\
\hline REERmis & -0.155 & 0.047 & -3.28 & 0.00 \\
DLOPENESS & -0.016 & 0.047 & -0.34 & 0.74 \\
DLSAVINGS & 0.061 & 0.027 & 2.30 & 0.03 \\
INFLATION & -0.004 & 0.001 & -3.46 & 0.00 \\
DLCRP & 0.002 & 0.053 & -0.04 & 0.97 \\
C & 4.657 & 0.011 & 418.69 & 0.00 \\
\hline
\end{tabular}

Panel B: Residuals Diagnostics Tests Results

$\mathrm{JB}_{\mathrm{N}}=1.37[0.50]$

$\chi^{2} \mathrm{BPG}=8.40[0.14]$

$\chi^{2} \mathrm{SC}(2)=9.75[0.01]$

$\mathrm{F}_{\mathrm{FF}}(1,48)=0.00[0.98]$

Note: The dependent variable real GDP per capita growth. $\mathrm{JB}_{\mathrm{N}}$ and $\mathrm{F}_{\mathrm{FF}}$ denotes the Jarque-Bera Normality and the Ramsey RESET Test statistics to test the null hypotheses of the normal distribution and no functional form misspecification, respectively, whilst the $\chi^{2} \mathrm{BPG}, \chi^{2} \mathrm{SC}(2)$ denotes the chi-squared statistics to test the null hypotheses of no heteroscedasticity and no serial correlation respectively in the residuals using the Breusch-Pagan-Godfrey Heteroskedasticity test and the Breusch-Godfrey Serial Correlation LM Test respectively. The $p$-values are given in brackets. Source: Author's calculations using EViews.

\subsection{Non-Linear Effects of Exchange Rate Misalignment on Economic Growth in TET}

We now examine whether the effects of real exchange misalignments on economic growth in the T\&T economy display any non-linear effects. Specifically, we examine the impact of overvaluations and undervaluations respectively on economic growth in the economy. In order to test these hypotheses, we define the dummy variable $D_{t}$ that takes the value of 1 when the REER is overvalued and 0 otherwise. Then, we define our variables of overvaluation and undervaluation of the REER as OVERVAL $=$ REERmis $* D_{t}$ and UNDEVAL $=$ REERmis $*\left(1-D_{t}\right)$.

To examine the impact of overvaluations and undervaluations respectively on economic growth in the T\&T economy, we estimate the following two models:

$$
\begin{gathered}
\mathrm{Y}=\mathrm{f}(\text { OVERVAL }, \text { Controls }) \\
\mathrm{Y}=\mathrm{f}(\text { UNDERVAL }, \text { Controls })
\end{gathered}
$$

where OVERVAL and UNDERVAL denote the overvaluation and undervaluation indices of the REER respectively and the control variables are the same as in Equation (3).

The results surprisingly do not point to any non-linear effects, with both the dummy for overvaluations and undervaluations returning negative signs (see Tables 6 and 7 respectively). Table 6 highlights that an overvaluation of $1 \%$ is associated with a decline in economic growth in the T\&T economy to the order of $-0.25 \%$. Table 7 on the other hand highlights that an undervaluation of $1 \%$ is associated with a decline in economic growth in the T\&T economy to the order of $-0.21 \%$. A possible reason for the fact that we find that an undervaluation does not promote economic growth in the T\&T economy is due to its small and underdeveloped manufacturing sector which accounts for roughly $7.4 \%$ of GDP for the period 1966 to $2014^{14}$. Furthermore, T\&T's manufacturing sector is heavily import-oriented, i.e., the sector relies heavily on imported materials/inputs in its production process. As such, undervaluations can result in an increase in cost push inflation in T\&T's manufacturing sector which ultimately reduces the competitiveness and profitability of the sector in line with the arguments put forth by Nunnenkamp and Schweickert (1990).

14 The share of manufacturing in GDP has been declining in the T\&T economy since 1998, averaging 6.4\% over the period 1998 to 2014. 
Table 6. REER overvaluation and economic growth.

\begin{tabular}{ccccc}
\hline \multicolumn{5}{c}{ Panel A: Estimated OLS Coefficients } \\
\hline Variables & Coefficient & Std. Error & $\boldsymbol{t}$-Statistic & Probability \\
\hline OVERVAL & -0.245 & 0.078 & -3.13 & 0.00 \\
DLOPENESS & -0.017 & 0.049 & -0.35 & 0.73 \\
DLSAVINGS & 0.065 & 0.027 & 2.41 & 0.02 \\
INFLATION & -0.004 & 0.001 & -3.61 & 0.00 \\
DLCRP & -0.011 & 0.053 & -0.22 & 0.83 \\
C & 4.672 & 0.012 & 400.33 & 0.00 \\
\hline
\end{tabular}

Panel B: Residuals Diagnostics Tests Results

$$
\begin{aligned}
\mathrm{JB}_{\mathrm{N}} & =1.49[0.48] \\
\chi^{2} \mathrm{BPG} & =4.52[0.20]
\end{aligned}
$$$$
\chi^{2} \mathrm{SC}(2)=10.70[0.01]
$$$$
\mathrm{F}_{\mathrm{FF}}(1,48)=0.10[0.76]
$$

Note: The dependent variable real GDP per capita growth. $\mathrm{JB}_{\mathrm{N}}$ and $\mathrm{F}_{\mathrm{FF}}$ denotes the Jarque-Bera Normality and the Ramsey RESET Test statistics to test the null hypotheses of the normal distribution and no functional form misspecification, respectively, whilst the $\chi^{2}$ BPG, $\chi^{2} S C(2)$ denotes the chi-squared statistics to test the null hypotheses of no heteroscedasticity and no serial correlation respectively in the residuals using the Breusch-Pagan-Godfrey Heteroskedasticity test and the Breusch-Godfrey Serial Correlation LM Test respectively. The $p$-values are given in brackets. Source: Author's calculations using EViews.

Table 7. REER undervaluation and economic growth.

\begin{tabular}{ccccc}
\hline \multicolumn{5}{c}{ Panel A: Estimated OLS Coefficients } \\
\hline Variables & Coefficient & Std. Error & $\boldsymbol{t}$-Statistic & Probability \\
\hline UNDERVAL & -0.212 & 0.090 & -2.36 & 0.02 \\
DLOPENESS & -0.004 & 0.049 & -0.08 & 0.94 \\
DLSAVINGS & 0.052 & 0.028 & 1.88 & 0.07 \\
INFLATION & -0.004 & 0.001 & -3.23 & 0.00 \\
DLCRP & -0.022 & 0.055 & -0.40 & 0.69 \\
C & 4.646 & 0.013 & 352.32 & 0.00 \\
\hline
\end{tabular}

Panel B: Residuals Diagnostics Tests Results

$\mathrm{JB}_{\mathrm{N}}=0.97[0.62]$

$\chi^{2} \mathrm{BPG}=11.43[0.05]$

$\chi^{2} \mathrm{SC}(2)=7.86[0.02]$

$\mathrm{F}_{\mathrm{FF}}(1,48)=0.51[0.48]$

Note: The dependent variable real GDP per capita growth. $\mathrm{JB}_{\mathrm{N}}$ and $\mathrm{F}_{\mathrm{FF}}$ denotes the Jarque-Bera Normality and the Ramsey RESET Test statistics to test the null hypotheses of the normal distribution and no functional form misspecification, respectively, whilst the $\chi^{2}$ BPG, $\chi^{2} S C(2)$ denotes the chi-squared statistics to test the null hypotheses of no heteroscedasticity and no serial correlation respectively in the residuals using the Breusch-Pagan-Godfrey Heteroskedasticity test and the Breusch-Godfrey Serial Correlation LM Test respectively. The $p$-values are given in brackets. Source: Author's calculations using EViews.

The literature highlights that an undervalued exchange rate promotes economic growth in developing economies through an increase in investment in the traded goods sector or manufacturing which is ultimately assumed to be the most productive sector in the economy, and ultimately boosts overall economic growth. However, unlike other developing economies in particular China and other east-Asian economies that experienced rapid and sustained growth through currency undervaluations, T\&T as with other resource rich economies tend to be heavily dependent and reliant on its natural resources for both export and output growth in the economy. As such, this study proffers that the recommendation of maintaining a moderately undervalued currency in developing economies proffered in the literature may not be applicable to developing resource-rich economies where the manufacturing sector tends to be small and underdeveloped. Indeed these results serve as a stepping stone for the conduct of further research into this finding for a panel of resource-rich developing economies. 


\section{Conclusionand Policy Recommendations}

This paper examined the impact of exchange rate movements as well as exchange rate misalignments on economic growth for the Trinidad and Tobago economy over the period 1960 to 2016. Empirical studies (Aguirre and Calderón 2005; Rodrik 2008) have demonstrated that developing countries experience economic growth through an undervalued exchange rate and that exchange rate overvaluations have negative long-term effects on economic growth. Conversely, the "Washington consensus view" holds that deviations away from REER equilibrium, i.e., both over and undervaluations affect economic growth negatively. In recent times, T\&T's foreign exchange reserves have been on the decline on account of the unexpected decline in oil prices experienced in mid-2014. In addition to waning foreign exchange reserves, the T\&T economy also experienced a rapid decline in growth, coupled with an increased stock of debt as fiscal deficits widened in addition to declining current account balances that deteriorated significantly. This resulted in added depreciation/devaluation pressures on the exchange rate for the T\&T economy, resulting in agencies such as the IMF indicating that the currency has been significantly overvalued as the state maintained a relative fixed exchange rate to the US\$.

Therefore, this paper firstly examined T\&T's exchange rate misalignments for the period 1960 to 2016 using an ARDL approach to assessing cointegration which was proposed by Pesaran and Smith (1995) and further developed by Pesaran et al. (2001). The results derived from the ARDL bound test indicated that there does in fact exist a cointegrating relationship amongst the REER and its fundamentals. In particular, the results of the ARDL model indicated that increases in output, government spending, net foreign assets and the oil price all result in an appreciation of the exchange rate in the T\&T economy. Conversely, increases in credit to the private sector and the level of foreign exchange reserves has a depreciating impact on the exchange rate, however, the former is not statistically significant at any conventional levels of statistical significance.

Given that a long-run relationship was found, we subsequently estimated T\&T's exchange rate misalignments as the difference between the natural log of REER and the natural log of the estimated equilibrium real effective exchange rate (EREER). The results highlighted that T\&T's exchange rate has in fact been overvalued since 2014, with the average overvaluation amounting to $5.66 \%$ with a peak of $9.5 \%$ in 2015 . The paper subsequently examined the impact of both exchange rate movements and misalignments on economic growth. The results highlighted that both exchange rate appreciation and misalignments impact negatively on economic growth in the T\&T economy. Additionally, we find that there exists no non-linear effects of exchange rate misalignments on growth. Specifically, we find statistically significant evidence that both overvaluations and undervaluations hamper economic growth in the Trinidad and Tobago economy.

Given T\&T's heavy reliance on the energy sector, a major policy concern lies in relation to the impact that fluctuations in the price of oil can have on the REER. Oil price fluctuations can be transmitted to the domestic economy through the fiscal channel, see Pieschacón (2012) and Lorde et al. (2009). Lorde et al. (2009) highlighted empirically that oil price volatility is transmitted through the fiscal policy channel on T\&T's domestic economy. Adding to this, Hosein et al. (2017) provided empirical evidence that T\&T followed a procyclical fiscal stance. This sub-optimal fiscal policy stance can have an overall bearing on the exchange rate during periods of booms and bust in the business cycle, which is strongly related to the energy sector and by extension, the price of oil in T\&T's case. During periods of booms, government spending increases and thus may lead to an appreciation of the currency and conversely, during downturns, government expenditure contracts resulting in depreciating pressures exerted on the currency. Hasanov et al. (2017) examined the impact the price of oil has on exchange rate movements for three oil exporters, namely Azerbaijan, Kazakhstan and Russia. The authors point out that policy makers should reconsider the fiscal policy stance adopted in these countries in lieu of a more countercyclical stance, since oil prices lead to an appreciation of the REER mainly through higher domestic prices, which is on account of excessive public spending. 
Raymond et al. (2017) investigated whether a sovereign wealth fund (SWF) helps to reduce real exchange rate misalignments by dampening the transmission of energy prices. In particular, Raymond et al. (2017) examined the relationship between a SWF and the REER and found that a SWF reduces the volatility of REER misalignments by dampening the transmission of energy prices. As noted in Hosein et al. (2017), a SWF plays a major role in economies such as T\&T given its large dependence on these resources. A major policy recommendation stemming from these findings in the paper would be for the critical reassessment of the rules governing T\&T's Heritage and Stabilization Fund (HSF), i.e., T\&T's SWF, as government expenditure was allowed to follow energy revenues due to its current limitations.

The HSF was officially legislated on the 15th of March 2007, replacing the Interim Revenue Stabilization Fund (IRSF) that covered the period 2000 to 2007. The purpose of the Fund is to save and invest surplus petroleum revenues derived from production business in order to achieve three main objectives. See the Heritage and Stabilization Fund Act, 2007 for an outline of these objectives (note this is footnoted in the updated manuscript). The surplus petroleum revenues are invested in external capital and money markets, under the management of the Central Bank of Trinidad and Tobago (CBTT). This investment of surplus petroleum revenues in external markets can then help to limit in the short run the pass through effects of oil price variations to the real exchange rate, Das et al. (2011). Raymond et al. (2017) points out that the Dutch disease effect, i.e., an appreciation of the real exchange rate following a resource windfall can be mitigated by investing part of the natural resource rents abroad.

It is pivotal, therefore, that the current rules be amended to allow for a larger proportion of the petroleum revenues to be saved in the HSF, which would allow for the decoupling of these revenues from the budgetary process in order to dampen the transmission of energy prices in the domestic economy, see Hosein et al. (2017). The rules governing the HSF need to play a significant role, in reducing the effects of oil prices on the domestic economy as well as the REER in the T\&T economy.

Author Contributions: Both authors contributed equally to the completion of this paper.

Funding: This research was funded by the Campus Research and Publication Fund Committee of the University of the West Indies, St. Augustine campus.

Acknowledgments: Thanks are due to Roger Hosein and Bhoendradatt Tewarie for useful comments made on earlier drafts of this paper. The authors also acknowledge Ms. Akeeta Ali for her invaluable research assistance.

Conflicts of Interest: The authors declare no conflict of interest. The funders had no role in the design of the study; in the collection, analyses, or interpretation of data; in the writing of the manuscript, and in the decision to publish the results.

\section{Appendix A}

Table A1. Displaying the composition of GDP in the T\&T economy over the period 1966 to 2014.

\begin{tabular}{ccccc}
\hline Year & $\begin{array}{c}\text { Petroleum Industry } \\
\text { Share of GDP }\end{array}$ & $\begin{array}{c}\text { Agriculture } \\
\text { Share of GDP }\end{array}$ & $\begin{array}{c}\text { Manufacturing } \\
\text { Share of GDP }\end{array}$ & $\begin{array}{c}\text { Services Share } \\
\text { of GDP }\end{array}$ \\
\hline 1966 & 26.5 & 6.7 & 7.0 & 61.4 \\
1967 & 27.6 & 6.5 & 7.7 & 59.5 \\
1968 & 29.6 & 6.8 & 7.9 & 57.6 \\
1969 & 25.1 & 6.8 & 9.5 & 61.1 \\
1970 & 22.3 & 6.6 & 10.3 & 62.6 \\
1971 & 20.6 & 6.6 & 10.4 & 64.7 \\
1972 & 20.8 & 7.1 & 10.7 & 63.4 \\
1973 & 27.7 & 5.7 & 9.6 & 59.2 \\
1974 & 44.3 & 4.6 & 6.7 & 46.6 \\
1975 & 43.4 & 5.0 & 6.3 & 48.3 \\
1976 & 42.2 & 4.9 & 6.9 & 49.8 \\
1977 & 41.2 & 4.1 & 7.2 & 51.5 \\
1978 & 34.8 & 3.7 & 7.2 & 58.7 \\
1979 & 38.6 & 3.4 & 6.5 & 56.8 \\
1980 & 42.8 & 2.6 & 5.3 & 54.3 \\
\hline
\end{tabular}


Table A1. Cont.

\begin{tabular}{|c|c|c|c|c|}
\hline Year & $\begin{array}{l}\text { Petroleum Industry } \\
\text { Share of GDP }\end{array}$ & $\begin{array}{c}\text { Agriculture } \\
\text { Share of GDP }\end{array}$ & $\begin{array}{l}\text { Manufacturing } \\
\text { Share of GDP }\end{array}$ & $\begin{array}{c}\text { Services Share } \\
\text { of GDP }\end{array}$ \\
\hline 1981 & 35.7 & 2.6 & 5.0 & 61.0 \\
\hline 1982 & 26.1 & 2.4 & 5.2 & 70.3 \\
\hline 1983 & 24.4 & 2.1 & 7.3 & 70.2 \\
\hline 1984 & 27.2 & 1.3 & 7.4 & 68.2 \\
\hline 1985 & 26.6 & 2.4 & 7.3 & 68.1 \\
\hline 1986 & 22.7 & 2.8 & 8.2 & 70.7 \\
\hline 1987 & 25.2 & 2.8 & 8.3 & 67.8 \\
\hline 1988 & 24.1 & 2.7 & 8.7 & 68.2 \\
\hline 1989 & 27.2 & 2.5 & 9.6 & 64.5 \\
\hline 1990 & 29.6 & 2.5 & 8.6 & 57.6 \\
\hline 1991 & 26.2 & 2.5 & 9.1 & 60.5 \\
\hline 1992 & 23.6 & 2.5 & 9.2 & 65.0 \\
\hline 1993 & 23.3 & 2.6 & 9.3 & 65.3 \\
\hline 1994 & 29.9 & 2.2 & 7.8 & 59.0 \\
\hline 1995 & 27.5 & 2.3 & 8.2 & 60.3 \\
\hline 1996 & 29.1 & 2.1 & 7.0 & 60.3 \\
\hline 1997 & 25.5 & 2.2 & 7.9 & 63.8 \\
\hline 1998 & 18.5 & 2.1 & 9.1 & 68.4 \\
\hline 1999 & 22.5 & 1.9 & 8.0 & 67.0 \\
\hline 2000 & 31.3 & 1.4 & 7.1 & 60.7 \\
\hline 2001 & 28.3 & 1.3 & 7.4 & 62.9 \\
\hline 2002 & 26.2 & 1.4 & 8.0 & 64.0 \\
\hline 2003 & 36.0 & 0.9 & 6.9 & 56.3 \\
\hline 2004 & 38.7 & 0.8 & 7.5 & 52.9 \\
\hline 2005 & 45.9 & 0.5 & 5.5 & 48.0 \\
\hline 2006 & 47.0 & 0.6 & 5.6 & 46.3 \\
\hline 2007 & 45.0 & 0.4 & 5.3 & 48.9 \\
\hline 2008 & 50.8 & 0.4 & 4.0 & 44.3 \\
\hline 2009 & 34.6 & 0.6 & 5.8 & 59.3 \\
\hline 2010 & 42.0 & 0.6 & 5.5 & 51.8 \\
\hline 2011 & 45.6 & 0.6 & 5.6 & 48.7 \\
\hline 2012 & 41.2 & 0.6 & 6.2 & 51.3 \\
\hline 2013 & 43.4 & 0.5 & 5.5 & 49.7 \\
\hline 2014 & 42.1 & 0.5 & 5.6 & 50.9 \\
\hline
\end{tabular}

Source: Own table using CBTT Handbook of Key Economic Indicators data.

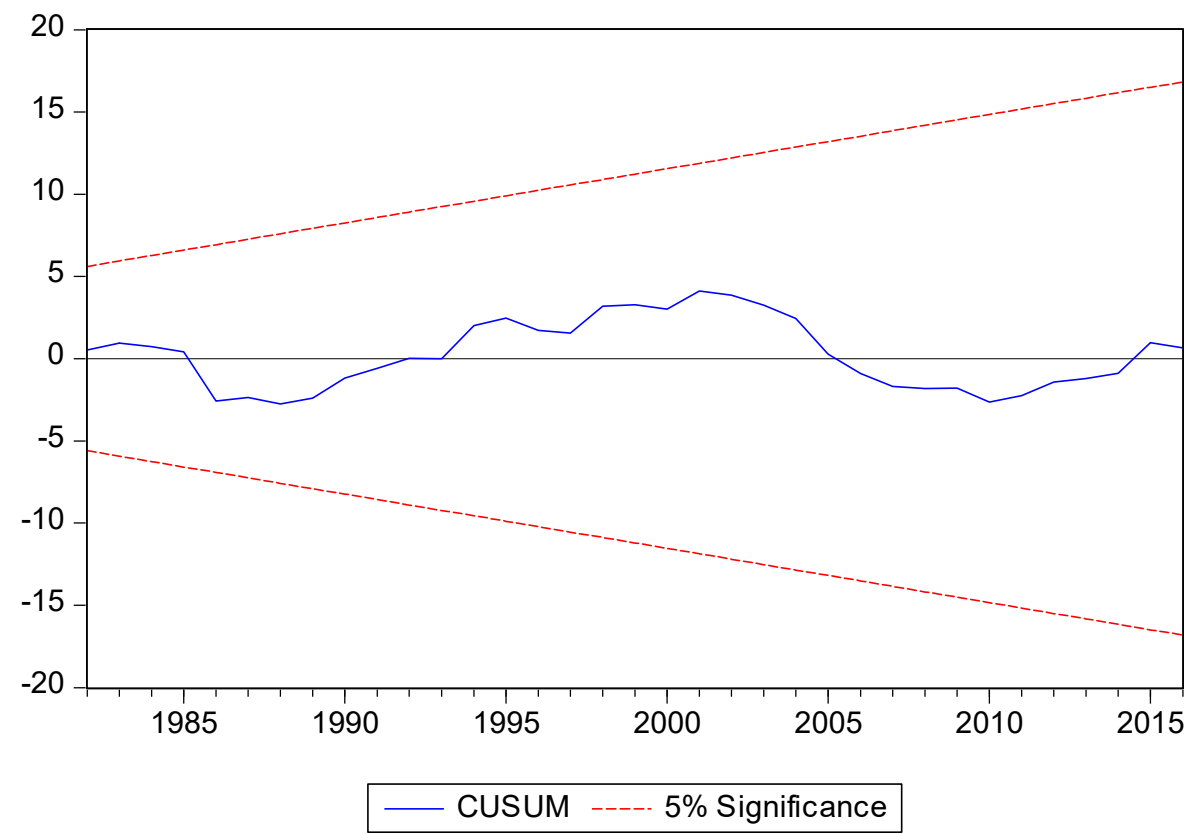

Figure A1. Cumulative Sum (CUSUM) stability test. 


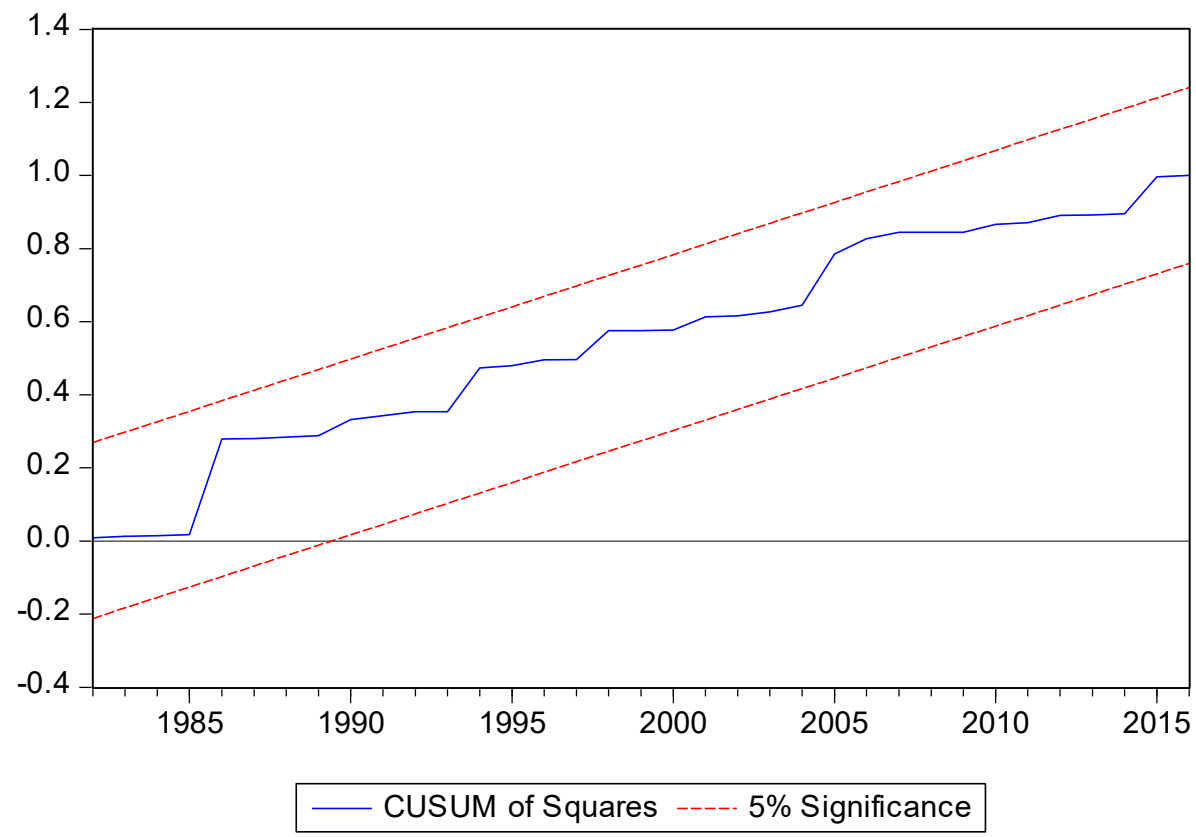

Figure A2. Cumulative Sum of Squares (CUSUMQ) stability test.

\section{References}

Acaravci, Ali, and Ilhan Ozturk. 2012. Foreign Direct Investment, Export and Economic Growth: Empirical Evidence from New EU Countries. Journal of Economic Forecasting 2: 52-67.

Acosta, Pablo A., Emmanuel K. K. Lartey, and Federico S. Mandelman. 2009. Remittances and the Dutch disease. Journal of International Economics 79: 102-16. [CrossRef]

Aguirre, Alvaro, and César Calderón. 2005. Real Exchange Rate Misalignments and Economic Performance. Central Bank of Chile Working Papers No. 315. Santiago: Central Bank of Chile.

Aizenman, Joshua, and Jaewoo Lee. 2010. Real Exchange Rate, Mercantilism and the Learning by Doing Externality. Pacific Economic Review 15: 324-35. [CrossRef]

Alberola, Enrique. 2003. Misalignment, Liabilities Dollarization and Exchange Rate Adjustment in Latin America Banco de España Research Paper No. WP-0309. August 11. Available online: https://ssrn.com/abstract= 981338 (accessed on 18 April 2018). [CrossRef]

Arellano, Manuel, and Stephen Bond. 1991. Some Tests of Specification for Panel Data: Monte Carlo Evidence and an Application to Employment Equations. Review of Economic Studies 58: 277-97. [CrossRef]

Arellano, Manuel, and Olympia Bover. 1995. Another look at the instrumental variable estimation of error-components models. Journal of Econometrics 68: 29-51. [CrossRef]

Beckmann, Joscha, and Robert Czudaj. 2013. Oil prices and effective dollar exchange rates. International Review of Economics \& Finance 27: 621-36. [CrossRef]

Benigno, Gianluca, Nathan Converse, and Luca Fornaro. 2015. Large capital inflows, sectoral allocation, and economic performance. Journal of International Money and Finance 55: 60-87. [CrossRef]

Béreau, Sophie, Antonia López Villavicencio, and Valérie Mignon. 2012. Currency misalignments and growth: A new look using nonlinear panel data methods. Applied Economics 44: 3503-11. [CrossRef]

Berg, Andrew, and Yanliang Miao. 2010. The Real Exchange Rate and Growth Revisited: The Washington Consensus Strikes Back? IMF Working Papers No. 10/58. Washington, DC: International Monetary Fund.

Bhalla, Surjit S. 2007. Economic development and the role of currency undervaluation. The Cato Journal 28: 313.

Blackman, Courtney. 2002. Factors in the Choice of Exchange Rate Regime with special reference to the Caribbean. Paper Presented at the XXXIV Annual Monetary Studies Conference, Georegetown, Guyana, 12-16 November 2002.

Bresser-Pereira, Luiz Carlos. 2008. The Dutch Disease and Its Neutralization: A Ricardian Approach. Revista de Economia Politica/Brazilian Journal of Political Economy 28: 47-71. [CrossRef] 
Brown, Robert L., James Durbin, and James M. Evans. 1975. Techniques for Testing the Constancy of Regression Relationships over Time. Journal of the Royal Statistical Society. Series B (Methodological) 37: 149-92.

Corden, W. Max, and J. Peter Neary. 1982. Booming Sector and De-Industrialisation in a Small Open Economy. The Economic Journal 92: 825-48. [CrossRef]

Cottani, Joaquin A., Domingo F. Cavallo, and M. Shahbaz Khan. 1990. Real Exchange Rate Behavior and Economic Performance in LDCs. Economic Development and Cultural Change 39: 61-76. [CrossRef]

Darvas, Zsolt. 2012. Real Effective Exchange Rates for 178 Countries: A New Database. St. Louis: Federal Reserve Bank of St Louis.

Das, Udaibir S., Adnan Mazarei, and Han Van Der Hoorn, eds. 2011. Economics of Sovereign Wealth Funds: Issues for Policymakers. Washington, DC: IMF.

Di Nino, Virginia, Barry Eichengreen, and Massimo Sbracia. 2011. Real Exchange Rates, Trade, and Growth: Italy 1861-2011. St. Louis: Federal Reserve Bank of St Louis.

Dollar, David. 1992. Outward-Oriented Developing Economies Really Do Grow More Rapidly: Evidence from 95 LDCs, 1976-1785. Economic Development and Cultural Change 40: 523-44. [CrossRef]

Doroodian, K., Chulho Jung, and Ahmet Yucel. 2002. Estimating the Equilibrium Real Exchange Rate: The Case of Turkey. Applied Economics 34: 1807-12. [CrossRef]

Edwards, Sebastian. 1989. Exchange Rate Misalignment in Developing Countries. The World Bank Research Observer 4: 3-21. [CrossRef]

Elbadawi, Ibrahim A., and Gerry Helleiner. 2005. African Development in the Context of the New World Trade and Financial Regimes: The Role of the WTO and its Relationship to the World Bank and IMF. In Africa and the World Trading System, Vol. I: Selected Issues of the Doha Agenda. Edited by Ademola Oyejide and William Lyakurwa. Trenton: Africa World Press, Inc.

Elbadawi, Ibrahim A., Linda Kaltani, and Raimundo Soto. 2012. Aid, Real Exchange Rate Misalignment, and Economic Growth in Sub-Saharan Africa. World Development 40: 681-700. [CrossRef]

Fatai, Koli, Les Oxley, and Frank G. Scrimgeour. 2003. Modeling and Forecasting the Demand for Electricity in New Zealand: A Comparison of Alternative Approaches. The Energy Journal 24: 75-102. [CrossRef]

Frankel, Jeffrey A., and Andrew K. Rose. 1996. Currency crashes in emerging markets: An empirical treatment. Journal of International Economics 41: 351-66. [CrossRef]

Freund, Caroline, and Martha Denisse Pierola. 2008. Export Surges: The Power of a Competitive Currency. Policy Research Working Paper No. 4750. Washington, DC: World Bank.

Frieden, Jeffry. 2008. Globalization and Exchange Rate Policy. In The Future of Globalization. Edited by Ernesto Zedillo. New York: Routledge, pp. 344-57.

Gala, Paulo, and Claudio R. Lucinda. 2006. Exchange rate misalignment and growth: Old and new econometric evidence. Journal of Economic Literature 7: 165-87.

Gasmi, Farid, and Imène Laourari. 2017. Has Algeria Suffered from the Dutch Disease? Evidence from 1960-2013 Data. TSE Working Papers 17-780. Toulouse: Toulouse School of Economics (TSE).

Ghura, Dhaneshwar, and Thomas J. Grennes. 1993. The real exchange rate and macroeconomic performance in Sub-Saharan Africa. Journal of Development Economics 42: 155-74. [CrossRef]

Glüzmann, Pablo Alfredo, Eduardo Levy-Yeyati, and Federico Sturzenegger. 2012. Exchange rate undervaluation and economic growth: Díaz Alejandro (1965) revisited. Economics Letters 117: 666-72. [CrossRef]

Habib, Maurizio Michael, Elitza Mileva, and Livio Stracca. 2017. The real exchange rate and economic growth: Revisiting the case using external instruments. Journal of International Money and Finance 73: 386-98. [CrossRef]

Hasanov, Fakhri, Jeyhun Mikayilov, Cihan Bulut, Elchin Suleymanov, and Fuzuli Aliyev. 2017. The Role of Oil Prices in Exchange Rate Movements: The CIS Oil Exporters. Economies 5: 13. [CrossRef]

Hodrick, Robert J., and Edward C. Prescott. 1997. Postwar U.S. Business Cycles: An Empirical Investigation. Journal of Money, Credit, and Banking 29: 1-16. [CrossRef]

Hosein, Roger, Jaymieon Jagessar, and Isaac Dialsingh. 2017. Procyclical Tendencies in a Small Oil Exporter. Economia Internazionale/International Economics 70: 319-31.

Ibrahim, Wahe. 2016. Econometric analysis of determinants of real effective exchange rate in Nigeria (1960-2015). Timisoara Journal of Economics and Business 9: 62-80. [CrossRef]

Johnson, Simon, Jonathan D. Ostry, and Arvind Subramanian. 2006. Levers for Growth: Policy Lessons from Earlier Bouts of Growth in Developing Countries. Finance and Development 43: number 1. 
Kaminsky, Graciela L., and Carmen M. Reinhart. 1999. The Twin Crises: The Causes of Banking and Balance-of-Payments Problems. The American Economic Review 89: 473-500. [CrossRef]

Koranchelian, Taline. 2005. The Equilibrium Real Exchange Rate in a Commodity Exporting Country: Algeria's Experience. IMF Working Papers: 05/135. Washington, DC: International Monetary Fund.

Krueger, Anne O. 1983. Exchange Rate Determination. Cambridge: Cambridge University Press.

Krugman, Paul. 1979. A Model of Balance-of-Payments Crises. Journal of Money, Credit and Banking 11: 311-25. [CrossRef]

Krugman, Paul, and Lance Taylor. 1978. Contractionary effects of devaluation. Journal of International Economics 8: 445-56. [CrossRef]

Levy-Yeyati, Eduardo, and Federico Sturzenegger. 2007. Fear of Appreciation. World Bank Policy Research Working Paper 4387. Washington, DC: The World Bank.

Loayza, Norman, Pablo Fajnzylber, and Cesar Calderon. 2005. Economic Growth in Latin America and the Caribbean: Stylized Facts, Explanations, and Forecasts. Washington, DC: World Bank.

López Villavicencio, Antonia, and Josep Lluís Raymond Bara. 2008. Short run and long run determinants of the real exchange rate in Mexico. Developing Economies 46: 52-74. [CrossRef]

Lorde, Troy, Mahalia Jackman, and Chrystol Thomas. 2009. The macroeconomic effects of oil price fluctuations on a small open oil-producing country: The case of Trinidad and Tobago. Energy Policy 37: 2708-16. [CrossRef]

Matsuyama, Kiminori. 1992. Agricultural productivity, comparative advantage and economic growth. Journal of Economic Theory 58: 317-34. [CrossRef]

Mbaye, Samba. 2013. Currency undervaluation and growth: Is there a productivity channel? International Economics 133: 8-28. [CrossRef]

McLeod, Darryl, and Elitza Mileva. 2011. Real Exchange Rates and Growth Surges. Fordham Economics Discussion Paper Series dp2011-04. New York: Department of Economics, Fordham University.

Missio, Fabrício J., Frederico G. Jayme Jr., Gustavo Britto, and José Luis Oreiro. 2015. Real Exchange Rate and Economic Growth: New Empirical Evidence. Metroeconomica 66: 686-714. [CrossRef]

Montiel, Peter J. 1999. Determinants of the long-run equilibrium exchange rate: An analytical model. In Exchange Rate Misalignment: Concepts and Measurement for Developing Countries. Edited by Lawrence E. Hinkle and Peter J. Monteil. Oxford: Oxford University Press, pp. 264-92.

Narayan, Paresh Kumar. 2004. An Econometric Model of Tourism Demand and a Computable General Equilibrium Analysis of the Impact of Tourism: The Case of the Fiji Islands. Ph.D. thesis, Department of Economics, Monash University, Melbourne, Australia. unpublished.

Narayan, Paresh Kumar. 2005. The Saving and Investment Nexus for China: Evidence from Cointegration Tests. Applied Economics 37: 1979-90. [CrossRef]

Naseem, N. A. M., Hui-Boon Tan, and M. S. Hamizah. 2009. Exchange rate misalignment, volatility and import flows in Malaysia. International Journal of Economics and Management 3: 130-50.

Nguyen, Nhung Thi Kim. 2017. The long run and short run impacts of foreign direct investment and export on economic growth of Vietnam. Asian Economic and Financial Review 7: 519-27. [CrossRef]

Nunnenkamp, Peter, and Rainer Schweickert. 1990. Adjustment Policies and Economic Growth in Developing Countries-Is Devaluation Contractionary? Weltwirtschaftliches Archiv 126: 474-93. [CrossRef]

Pesaran, Hashem Mohammad, and Barham Pesaran. 1997. Microfit 4.0. Oxford: Oxford University Press.

Pesaran, M. Hashem, and Yongcheol Shin. 1999. An autoregressive distributed lag modelling approach to cointegration analysis. In Econometrics and Economic Theory in the 20th Century: The Ragnar Frisch Centennial Symposium. Edited by Steiner Strom. Cambridge: Cambridge University Press.

Pesaran, M. Hashem, and Ron Smith. 1995. Estimating long-run relationships from dynamic heterogeneous panels. Journal of Econometrics 68: 79-113. [CrossRef]

Pesaran, M. Hashem, Yongcheol Shin, and Richard J. Smith. 2001. Bounds Testing Approaches to the Analysis of Level Relationships. Journal of Applied Econometrics 16: 289-326. [CrossRef]

Pieschacón, Anamaría. 2012. The value of fiscal discipline for oil-exporting countries. Journal of Monetary Economics 59: 250-68. [CrossRef]

Rapetti, Martin, Peter Skott, and Arslan Razmi. 2012. The Real Exchange Rate and Economic Growth: Are Developing Countries Different? International Review of Applied Economics 26: 735-53. [CrossRef] 
Raymond, Hélène, Coulibaly Dramane, and Luc-Désiré Omgba. 2017. Exchange rate misalignments in energy-exporting countries: Do sovereign wealth funds matter? International Economics 152: 124-44. [CrossRef]

Razin, Ofair, and Susan M. Collins. 1999. Real Exchange Rate Misalignments and Growth. In The Economics of Globalization: Policy Perspectives from Public Economics. Edited by Assaf Razin and Efraim Sadka. Cambridge, New York and Melbourne: University Press, pp. 59-81.

Rodrik, Dani. 2008. The Real Exchange Rate and Economic Growth. Brookings Papers on Economic Activity 2008: 365-412. [CrossRef]

Rodrik, Dani. 2009. Industrial Policy: Don't Ask Why, Ask How. Middle East Development Journal 1: 1-29. [CrossRef]

Salim, Nor Jana, Rajmi Mustaffa, and Nor Jawanees Ahmad Hanafiah. 2015. FDI and Economic Growth Linkages in Malaysia. Mediterranean Journal of Social Sciences 6: 652-57. [CrossRef]

Sami, Janesh, and Fuad Kreishan. 2012. FDI and export-led growth in jordan: Evidence from cointegration and causality test. Economics Bulletin 32: 1-18.

Sokolova, Maria V. 2015. Exchange Rates and Economic Growth: Re-Evaluation of Undervaluation. ADBI Working Paper Series No. 684. Tokyo: Asian Development Bank Institute.

Williamson, John. 1990. What Washington Means by Policy Reform. In Latin American Adjustment: How Much Has Happened? Edited by John Williamson. Washington, DC: Institute for International Economics.

Wondemu, Kifle Asfaw, and David J. Potts. 2016. The Impact of the Real Exchange Rate Changes on Export Performance in Tanzania and Ethiopia. Working Paper 240, Working Paper Series 2348. Abidjan: African Development Bank.

Zalduendo, Juan. 2006. Determinants of Venezuela's Equilibrium Real Exchange Rate. IMF Working Papers: 06/74. Washington, DC: International Monetary Fund.

(C) 2018 by the authors. Licensee MDPI, Basel, Switzerland. This article is an open access article distributed under the terms and conditions of the Creative Commons Attribution (CC BY) license (http:/ / creativecommons.org/licenses/by/4.0/). 